\title{
Correction to: A Celebration of History, Scientific Progress, and Pioneers Who Revolutionized Materials Science
}

\author{
JONATHAN D. MADISON ${ }^{1,2}$ \\ 1.-Alexandria, VA, USA. 2.—e-mail: jonathandmadison@gmail.com
}

Correction to:

JOM

https://doi.org/10.1007/s11837-021-05126-7

This article was updated to correct the author list.
Publisher's Note Springer Nature remains neutral with regard to jurisdictional claims in published maps and institutional affiliations. 